\title{
POLISH NAVY SHIPBUILDING REGULATIONS - EXAMPLE OF NEGLECT AND LACK OF AWARENESS. POLEMICAL SKETCH
}

\section{Arkadiusz Kalinowski ${ }^{\circledR}$}

e-mail: akali@poczta.wp.pl; ORCID ID: 0000-0002-5130-726X

\begin{abstract}
The paper presents a formal and legal status within the scope of design, construction and equipping the Polish Navy ships. Regulations in force in the Ministry of National Defence are not complete and have a significant impact on the possibilities and limited efficiency of building new ships.

The article presents an attempt to systematise issues in terms of the construction of new ships for the Polish Navy. Fundamental attention was focused on identification of existing gaps in the regulations, as well as presenting proposals to eliminate them.
\end{abstract}

Key words:

maritime classification society, military equipment acquisition system, regulations, shipbuilding, navy logistics.

\section{Research article}

(C) 2019 Arkadiusz Kalinowski This is an open access article licensed under the Creative Commons Attribution-NonCommercial-NoDerivatives 4.0 license (http://creativecommons.org/licenses/by-nc-nd/4.0/) 


\section{INTRODUCTION}

On November 28, 2017, the new MCMV (mine countermeasure vessel or mine-hunter) ORP 'Kormoran' was commissioned by the Polish Navy (fig. 1). It is the first ship since 24 years, from the time of launching and commissioned in 1994, the minesweeper ORP 'Wdzydze'1, completely designed and built by the Polish shipyard, in accordance with its original purpose. The younger vessel in the Polish Navy is the logistical support ship ORP 'Kontradmirał Xawery Czernicki', whose hull was rebuilt from the 19th unclaimed degaussing station from the series of ships ordered by the Soviet Navy (launched in 1991, taken over in March 1999 by the Polish Navy and commissioned by the Polish Navy in 2001). In the above context the ORP 'Śląsk' should also be mentioned - offshore patrol vessel (ex. ORP 'Gawron' - multipurpose corvette), which design work started in 1997 (construction began in 2001, launched in 2015), and the process of building it has not been completed to this day.

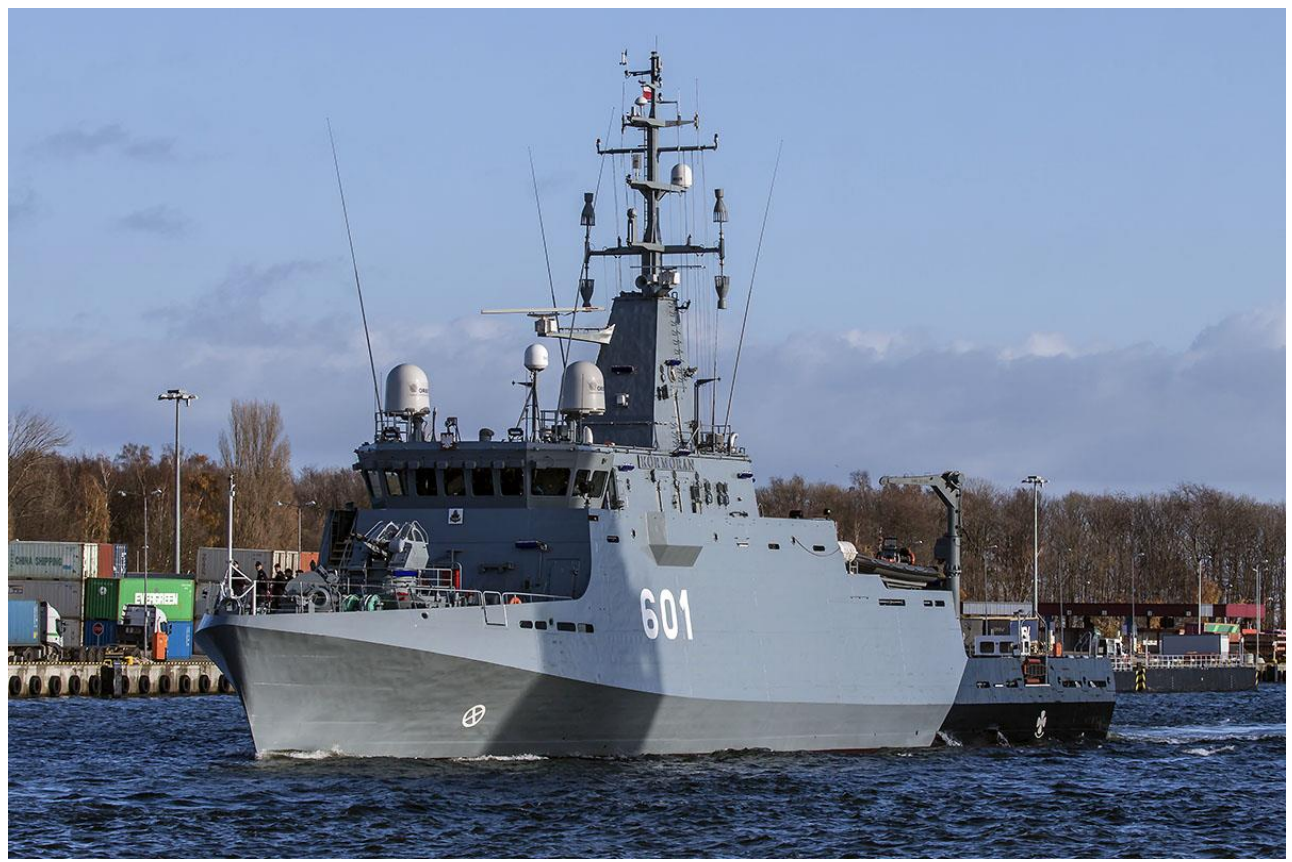

Fig. 1. ORP ‘Kormoran’ during transfer from Remontowa Shipbuilding S.A. yard in Gdańsk to the Naval Base in Gdynia, after harbour and sea trials completed on November 17, 2017 [12] in Gdynia.

${ }^{1}$ The last minesweeper in the series of ships project 207M built by the Naval Shipyard 
The status of naval forces of the Polish Navy determines both problems with acqusition of new ships, as well as the necessity of withdrawing ships which ended the period of technical capacity ('resurs') e.g. in 2017, after 53 years of exploitation in the Norwegian Navy (1964-2004) and in the Polish Navy (2004-2017), ORP 'Kondor' the first of four Polish submarines Kobben type was decommissioned (fig. 2). The second ship of this type ORP 'Sokół' was withdrawn on June 8, 2018 (exploitation 51 years).

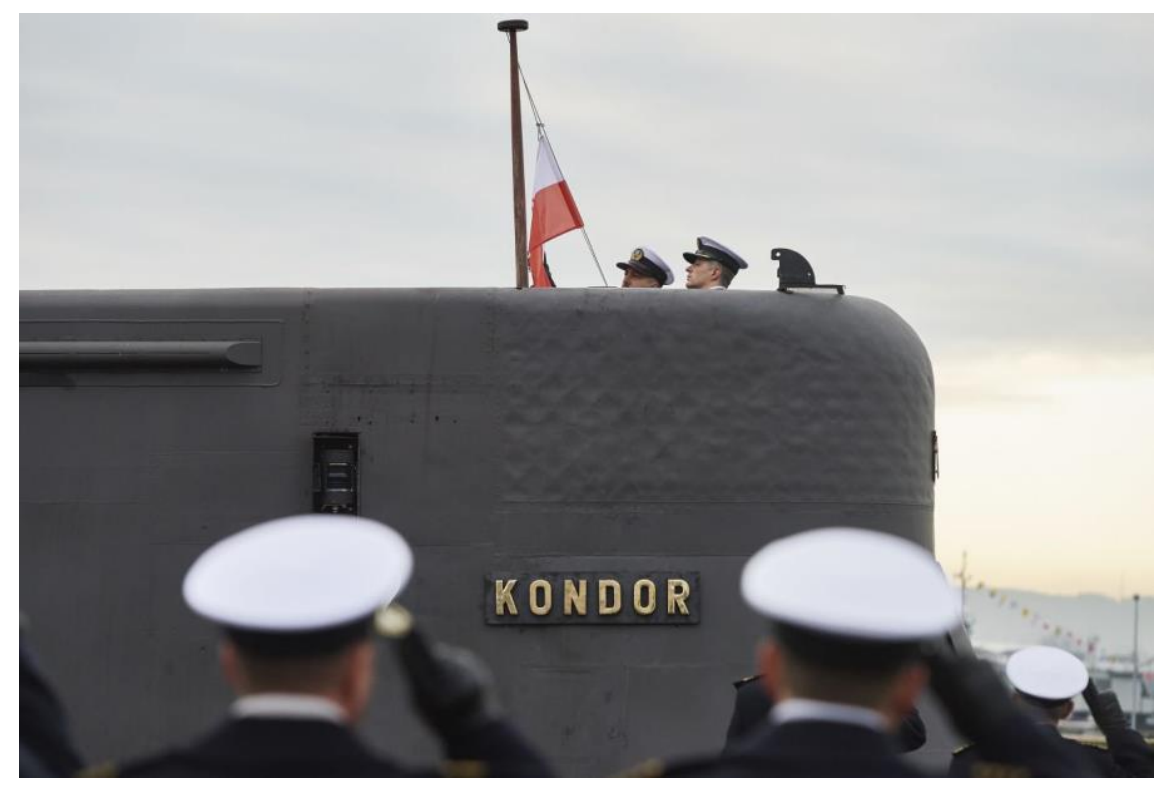

Fig. 2. 20 December 2017, the ceremony of leaving the flag at the ORP 'Kondor', end of service in the Polish Navy [14]

The average age of ships in the Polish Navy is over 30 years. In the current situation, the increase of the combat capability of the Polish Navy is possible only through the construction and commission of new warships (combat, assault). However, the above requires ordering and good preparation in terms of formal, legal and organizational processes of shipbuilding, appropriate financial expenditures, time for implementation and well educated, conscious and determined personnel.

The basis for the construction of new ships for the Polish Navy should be comprehensive and current shipbuilding regulations. It turns out that in this area for years there is a lack of awareness and we apply a makeshift solutions. 


\section{SELECTED PHRASES AND THEIR DEFINITIONS}

In terms of phrases in relation to shipbuilding there is one fundamental phrase: shipbuilding regulations. It is surprising that it is not properly understood by a lot of people. They give it a different meaning which not correspond with reality.

The phrase: shipbuilding regulations, in an inncorect and unauthorized manner, is colloquially used interchangeably with reference to a set of tactical, technical and equipment requirements (which are the parts of operational requirements, common staff targets, common staff requirements, tactical and technical assumptions, classification requirements, etc.) which should be met during the design and construction of a ship and in fact throughout the life cycle of the ship or the broadly understood military marine technology, often defined in the Polish Ministry of National Defence as ordinary military equipment or armaments and military equipment.

In shipbuilding area, there are the following selected basic phrases and their definitions, chosen from: Instruction on the principles of designing, construction and commissioning of naval ships of the Polish People's Republic built in the Polish shipyards [3], Rules for the classification and construction of Naval Ships (NS) [4], Decision of the Ministry of National Defence No. 141/MON of 5 July 2017 regarding to the system of acquisition, using and withdrawing military equipment of the Armed Forces of the Republic of Poland [1] and Act of August 18, 2011 on maritime safety [8]:

- certificate - security document issued for a ship in accordance with the provisions of the act and international agreements [8];

- certificate of class - document issued by a recognized organization confirming the ability or adaptation of a ship for a particular use in accordance with the classification rules of that recognized organization [8];

- classification regulations - the requirements of recognized organization for the construction of the ship, its fixed equipment and equipping, as well as the maintenance of the ship and the procedures of ship inspection [8];

- life cycle of military equipment - all possible subsequent or related life stages of military equipment, i.e. in particular research and development, industrial design, production, utilization, repair, modernization, modification, maintenance, logistics, training, testing, withdrawal and disposal [1];

- military equipment acquisition system - system for the acquisition, utilization and withdrawal of military equipment, the process of obtaining military equipment and all its parts, components or subassemblies, technical material resources for military equipment and services, as well as supplies, services and construction 
works directly related to the military equipment and actions of those responsible in the Ministry of National Defence under this system [1];

- military equipment ${ }^{2}$ - equipment specially designed or adapted to military needs and intended for use as an armament, ammunition or war material [1];

- organization - classification institution performing tasks in the field of technical supervision of ships [8];

- recognized organization - organization recognized by the European Commission in accordance with the European Union rules on common rules and standards for organizations inspecting and reviewing ships (e.g. Polish Register of Shipping S.A.) [8];

- shipbuilding regulations - principles of preparation substantive grounds, principles of designing and conducting supervision and acceptance of work during the construction of ships for the Polish Navy [3];

- technical supervision - a survey of machinery and systems other than those subject to classification, installed on board, carried out to ascertain that the structure complies with the requirements of Conventions, Codes and other requirements specified by the customer [4].

\section{INTRODUCTION TO THE SYSTEM APPROACH}

A system approach to the analysis of the functioning of the military equipment acquisition system require treating it as a compact structure with a variety of inputs and outputs. Within this structure there are smaller elements, e.g. the subsystem of obtaining ships, which enable the processing of inputs into outputs in accordance with the objectives of the system, i.e. in the present case, delivering to the Polish Navy, corresponding to the requirements, new ships. The main elements of the organization of the military equipment acquisition system are the regulation (management) subsystem and the executive subsystem.

The subsystem of shipbuilding regulations (management) consists, among others, of the following elements:

2 Occurring in the documents of the Ministry of National Defence, created before the introduction of the phrase military equipment, the former phrase 'armaments and military equipment' (in Polish: UiSW - uzbrojenie i sprzęt wojskowy) is equal to the current phrase 'military equipment' (in Polish: SpW - sprzęt wojskowy). 
- organizational structure of the Polish Armed Forces (e.g. the General Staff of the Polish Armed Forces, the Navy Inspectorate of the General Command of Branches of Armed Forces, the Armament Inspectorate, Regional Military Representative Office, etc.);

- doctrinal objectives and the resulting needs in the technical modernization of the Polish Armed Forces (e.g. periodically defined by the General Staff of the Polish Army Forces during Identification of Needs for Operational Capabilities and documents of the National Security Strategy and in an existing documents: Strategy for the development of the national security system of the Republic of Poland 2022, Defence Concept of the Republic of Poland, etc.);

- tasks (e.g. described in Detailed Directions of Reconstruction and Modernization of the Polish Armed Forces, operational requirements, technical modernization plan, etc.).

Besides the elements of the executive system, in the field of shipbuilding, are in addition to the technical and technological subsystem (e.g. shipyards and their suppliers, machinery, etc.), also the social subsystem (e.g. employees and production teams created by them, project groups and their motivation and goals) and the economic subsystem (e.g. determining the possibilities of state financing for shipbuilding 3 ).

In system approach, the shipbuilding regulations should constitute the element of the military equipment acquisition system, constituting a set of rules describing in terms of formal, substantive, organizational and executive aspects, along with their mutual relations, how to proceed during the preparation, construction, acceptance and supervision on the construction of new ships for the Polish Navy and their subsequent operation, as well as decommissioned and up to their scrapping (disposal). Therefore, they should contain an interpretation which will provide guidance and answer questions in a clear way: how, in what time sequence, who and what actions should be performed in particular phases ${ }^{4}$ and stages ${ }^{5}$ of the ship's life cycle.

So, there is need to possess necessary procedures (principles and algorithms of activities), an indication of the institutions or persons responsible and

${ }^{3}$ Related to the economic situation of the country by allocating on the technical modernization of the Polish Armed Forces expenditures, whose size is correlated in percentage of GDP: in 2018 and 2019 no less than $2 \%$ of GDP, and then ascending to 2030 up to of $2.5 \%$ GDP.

4 Phases of the life cycle, in accordance with the Decision No. 141/MON: identification, analytical and conceptual, implementation, utilization and withdrawal.

5 Stages of the life cycle, in accordance with the Decision No. 141/MON: identification of needs for operational capabilities, defining operational requirements, determining the feasibility, defining assumptions for design, design and development, production and purchasing, introduction, utilization, support, disposal, liquidation. 
their competences, as well as the identification of organizational and personal resources.

The consequence of the system approach to the shipbuilding regulations is the need to respect in their contents the following rigors:

- strictnesses - must be clearly defined scope of their application;

- immutabilities - the changes must be within the scope of the provisions and be consequent (constituent elements can't be arbitrarily or temporarily attached to the regulations);

- completenesses - regulations can't contain regulations that do not belong to any of its constituent parts;

- separations - regulations can't contain elements that belong to other regulations;

- functionalities - the constituent elements of the regulations should be separated due to the functions being performed.

\section{TOPICALITY OF REGULATIONS}

From a formal point of view, in the area of construction of new ships, the Armament Inspectorate conducts shipbuilding based on:

- obsolete (from 1985!) Instruction on the principles of designing, construction and commissioning of naval ships of the Polish People's Republic built in the Polish shipyards [3], but no less important and significant for the process of obtaining ships, This publication was created and implemented during the construction of corvette ORP 'Kaszub', despite the annulment, it still retains substantive validity;

- Rules for the classification and construction of Naval Ships (NS) [4] issued by the Polish Register of Shipping S.A. (PRS S.A.), not accepted for use in the Ministry of National Defence, but only indirectly admitted to use, according to the Decision of the Minister of National Defence No. 72/MON [2] and No. 141/MON [1], due to lack of other substantive technical requirements in the field of navigation safety and compliance with tactical and technical requirements outside of common staff requirements, tactical and technical requirements etc.;

- Decision of the Ministry of National Defence No. 141/MON of 5 July 2017 regarding to the system of acquisition, using and withdrawing military equipment of the Armed Forces of the Republic of Poland [1]; 
- Defence Standards ${ }^{6}$ appropriate to the technical and equipment requirements of the Polish Navy ships;

- supervision by the PRS S.A. on the design, construction, reconstruction and modernization of ships.

In the field of shipbuilding Instruction on the principles of designing, construction and commissioning of naval ships of the Polish People's Republic built in the Polish shipyards ${ }^{7}$ can be considered as the former equivalent of the Decision of the Minister of National Defence No. 141/MON of 5 July 2017 regarding to the system of acquisition, using and withdrawing military equipment of the Armed Forces of the Republic of Poland.

Instruction on the principles of designing, construction and commissioning of naval ships of the Polish People's Republic built in the Polish shipyards, regulates the shipbuilding process as a whole. It has been introduced in the Armed Forces of the Polish People's Republic on January 1, 1986, pursuant to Ordinance No. 34 of the Main Inspector of Technique of the Polish Army, deputy Minister of National Defence of October 3, 1985. Supervision over the use of the Instruction was entrusted to the Head of Naval Technique ${ }^{8}$. The Instruction ${ }^{9}$ contains 12 factual chapters, coherently describing the process of preparation, construction, acceptance and commissioning of ships by the Polish Navy. It consists of:

a) Chapter I. Studies and Analysis:

- aim of studies and analysis,

- operational-tactical-economic analysis,

- operational and tactical tasks,

- military tactical-technical-economic analysis,

- initial tactical and technical requirements,

- conceptual design,

- tactical and technical requirements;

${ }^{6}$ The list of applicable Defence Standards is attached to Decision of the Minister of National Defence No. 136/MON of 26 June 2017 on the approval and introduction of standardization documents regarding defense and national security for use, Dz.Urz. MON 2017, 141.

7 There are different opinions (lawyers of the Ministry of National Defence and Office for Anticorruption Procedures) regarding the application or not, in the Ministry of National Defence this Instruction.

${ }^{8}$ At present, the Head of the Naval Technology Department of the Armament Inspectorate can be considered as the counterpart.

${ }^{9}$ Due to the very limited access to this document, it was decided to present its contents in detail. 
b) Chapter II. Ship design:

- initial project,

- technical project,

- supervision of naval design and collection;

c) Chapter III. Working documentation (workshop);

d) Chapter IV. Ships construction:

- substantive documents and supervision on the construction of ships,

- ship's crew,

- rules of using devices subjected to technical supervision during shipbuilding,

- changes during the construction of ships;

e) Chapter V. Trials and testing of ships during construction:

- captive trials,

- shipyards trials at the sea,

- acceptance tests: preparation for trials, delivery commission, acceptance commission, the tasks of the delivery commission, acceptance commission entitles, general rules;

f) Chapter VI. Rules of lists execution and mode of transfer spare parts and inventory:

- rules of lists execution of spare parts and inventory,

- mode of transfer spare parts and inventory by the shipyard;

g) Chapter VII. Transfer documentation;

h) Chapter VIII. Warranty:

- general rules,

- notification of the complaint,

- implementation of works,

- supervision and acceptance of work during the warranty period;

i) Chapter IX. Planning mode, placing orders and contracting for the construction of ships;

j) Chapter $X$. The mode of setting the price and financing the design and construction;

k) Chapter XI. Derogations and simplifications in the design and construction of ships;

l) Chapter XII. Commissioning of navy ships - exploitation and military tests.

In the 12 annexes to the Instruction are included general guidelines and formulas for preparing necessary documents, including:

- scope of initial tactical and technical requirements;

- scope of tactical and technical requirements;

2 (217) 2019 
- framework scope of projects preparation;

- delivery and acceptance protocol;

- list of spare parts (inventory) transfered to the ship (base);

- delivery and acceptance protocol of spare parts (inventory) transfered to the ship (base);

- delivery and acceptance protocol of replenishment of missing spare parts (inventory) delivered to the ship (base);

- framework scope of transfer documentation;

- complaint request;

- delivery and transfer protocol of the warranty repair works of ships by the shipyard;

- the decision of the Head of Naval Technique about the completion of development work;

- Catalog Card.

The layout and content of the Instruction are essentially coherent with the Decision No. 141/MON and may constitute a reference point (base document) for the preparation of new, current shipbuilding regulations, taking into account the terms used in the naming of NATO, for example: Staff Requirements - requirements but not assumptions as is used in the normative documents of Polish Ministry of National Defence.

\section{ABANDONMENT \& REACTION}

In the field of shipbuilding regulations as well as technical requirements, in various areas ${ }^{10}$, both the universally binding law and the administrative law (issued by competent ministries) are applicable.

The problem of the lack of introduction in the Ministry of National Defence, uniform, coherent and comprehensive technical regulations, concerning the principles of design, construction and equipment of the Polish Navy ships arose in connection with the adoption by the Sejm Act of November 9, 2000 on maritime safety ${ }^{11}$ [10]. The Act regulates maritime safety matters in the area of ship construction, its permanent

10 The Polish Navy ships are excluded from the obligation to apply some of the requirements to which civilian ships are subject.

11 Archival Act. Currently, Act of August 18, 2011 on maritime safety [5] is in force, which has retained the previous provisions in this regard. 
equipment and additional equipment, ship inspection, crew qualifications and composition, safe navigation and saving life at sea.

According to the art. 4 par. 1, above Act is not applicable to the Navy, Border Guard and Police ships, except to cases specified in the Act. At the same time, the legislator in art. 4 par. 2 (art. 4 par. 4 of the new Act) included the possibility of authorizing the Council of Ministers to embrace the relevant regulations of the Act above-mentioned ships (according to: security requirements for construction, fixed equipment and equipment specified in an international agreements and regulations of the Act art. 6 par. 1), but the relevant legal act, as regards the interest of the Ministry of National Defence (the Polish Navy), has not been issued by the Council of Ministers.

The actual situation is that the Polish Navy ships have been excluded from the jurisdiction of the Act without indicating the institution/person (the minister) who would have, a delegation to put into use shipbuilding regulations in the Ministry of National Defence.

Therefore, in years 2003-2005 on the basis of an agreement between the Naval Shipyard S.A. and the Polish Register of Ships S.A. as part of the supervision over the construction of the corvette design 621/1 'GAWRON', PRS S.A. developed Regulations of design and construction of naval ships of the Polish Navy. They consisted of nine out of ten planned, separate, specialized parts (volumes). Regulations included overall areas of ships building: design, construction and acceptance of ships of the Polish Navy. The tenth part concerning materials and welding is common to the regulations for war and civilian ships.

Planned for the introduction additional part of regulation did not come within the scope of the order due to the fact that PRS S.A. at that time did not have the necessary executive potential to develop a specific part of the regulations related to special systems and equipment (armament and command control system). The above regulations have not been put into use in the Polish Navy due to the discrepancies in the Ministry of National Defence regarding the interpretation of the existing legal situation.

In December 2005, ten parts of regulations of shipbuilding design and construction were transferred to the Ministry of National Defence, for approval and entry into service in the Armed Forces of the Republic of Poland. The entry into force of these regulations did not take place, and for the following years, repeated without results attempts to develop them uniformly and introduce it to use in the Ministry of National Defence.

The attempts made by PRS to launch Part XI - Special systems of warships, despite the correspondence between the Ministry of Economy and the Ministry of National Defence, did not lead to the launch of the process of their development. 
Various solutions were proposed, both organizational and legal, but the effect remained unchanged. In the absence of a decision of the Ministry of National Defence regarding the implementation or recognition of PRS regulations as a basis for supervision of ship design and construction, PRS decided to develop and implement in 2008 its own Rules for the classification and construction of Naval Ships (NS) [4], thus providing a tool for supervision of ships under construction.

Currently, PRS is preparing the Second Edition of these regulations, taking into account experience in the construction of new ships for the Polish Navy and international experience resulting from participation in the NATO, IMO, IACS, INSA and NSCA ${ }^{12}$ structures.

In this situation at the request of the Armament Inspectorate in Decision of the Minister of National Defence No. 72/MON of March 25, 2015 regarding to the acquisition of military equipment and services for the Armed Forces of the Republic of Poland [2] and later in Decision No. 141/MON of 5 July 2017 regarding to the system of acquisition, using and withdrawing military equipment of the Armed Forces of the Republic of Poland [1], where introduce 'temporary' entries related to the regulations of the maritime classification society's as follows ${ }^{13}$ :

\section{$\S 87$}

During the design, construction and equipping of ships and other vessels of the Polish Navy, technical requirements (in the scope of design, construction and equipment) of the classification society, under the supervision of which is the construction of the ship or other vessels will be apply.

\section{$\S 88$}

The technical specification for new ships or other vessels of the Polish Navy should take into account the condition of fulfilment the classification society requirements for design, construction and equipment of ships or other vessels of the Polish Navy.

In the Decision No. 141/MON lacks a reference to Instruction on the principles of designing, construction and commissioning of naval ships of the Polish People's Republic built in national shipyards [3].

Currently in Poland, there is only one institution that has statutory rights to develop shipbuilding regulations. It is the Polish Register of Shipping S.A. - company of the State Treasury, having a public utility character, which within the scope of its

12 Accordingly: North Atlantic Treaty Organization, International Maritime Organization, International Association of Classification Societies, International Naval Safety Association, Naval Ship Classification Association.

${ }^{13}$ From the Decision No. 141/MON. 
activity in accordance with art. 11 of Act of October 26, 2000 on the Polish Register of Shipping S.A. [9] deals, among others, with preparation of detailed technical requirements under the name 'Rules for classification and construction'.

However, in the opinion of the Office for Anticorruption Procedures, Act of October 26, 2000 on PRS S.A. refers to the preparation of classification and construction rules for civilian ships and other vessels, while the Polish Navy ships are classified as armaments and military equipment under separate regulations, and PRS S.A. did not receive direct statutory competences to develop regulations in the field of this kind of ships or authorization or recognition of the PRS competences by the Ministry of Defence, despite the efforts made in this case for years.

Moreover, under the current legal status, the Minister of National Defence does not have competences within the scope of authorizations granted to him for approving regulations or guidelines for the design and construction of ships, as universally binding acts despite similar powers in other countries of the alliance.

According to art. 2 par. 2 and par. 10 of Act of December 14, 1995 on the Office of the Minister of National Defence [7], the scope of the Minister of National Defence is to prepare the state's defence assumptions, including proposals regarding the development and structure of the Armed Forces and management of matters of supply material, technical and financial needs of the Armed Forces, while in accordance with $\S 1$ par. 1 lit. e of the Ordinance of the Council of Ministers of July 9, 1996 on the detailed scope of action of the Minister of National Defence [5], the Minister has only competence in the field of preparing state defense assumptions for elaborating and reviewing draft normative legal acts and other defence documents.

Since many years, the Department of Armament Policy of the Ministry of National Defence, during proceeding by the Legal Department changings to the Act on the Office of the Minister of National Defence, submits requests to incorporate in them the authorization of the Minister, to introduce into the Polish Armed Forces shipbuilding regulations, however they are not accepted.

Another problem is the issue of clearly identifying and possibly creation in the Ministry of National Defence a new organization called Naval Administration similar in its structure and scope of operation to the Maritime Administration of the State - Maritime Offices which is right to civil ships and other statutory references and operating in the field of navigational safety, technical security of ships, environmental protection, crew qualifications etc. 


\section{ACTIONS TAKEN BY THE MINISTRY OF THE INTERIOR AND ADMINISTRATION}

The problem of the lack of provisions concerning, among others construction of the Border Guards ships, was solved by the Ministry of the Interior and Administration by amending the Border Guard Act.

In art. 1 par. 25 of Act of April 11,2001 amending the act on the Border Guard and amending some other acts [6], were introduced art. 19 a par. 2, containing a delegation for the minister in charge of internal affairs, to accept, by way of order, the technical regulations regarding the construction and equipment of ships issued by the Polish classification society as valid for the ships of the Border Guard. Then, was introduce on the day of signing, Ordinance No. 6 of the Minister of the Interior and Administration of March 6, 2003 regarding the recognition of technical regulations in scope of the construction and equipment of ships issued by the Polish classification society as binding for the ships of the Border Guard [11].

The solution adopted in the Ministry of the Interior and Administration is an example of how a legal gap can be filled in with scope of inability of Minister of National Defence to apply the regulations for the design and construction of ships in the Polish Armed Forces.

\section{PRS S.A. - REGULATIONS FOR THE CLASSIFICATION AND CONSTRUCTION OF NAVAL SHIPS ${ }^{14}$}

PRS S.A. developed and issued independently in 2008 its own Rules for the classification and construction of Naval Ships (NS) [4], irrespective of previously developed at the request of Naval Shipyard S.A., in connection with the implementation of the agreement on the construction of the corvette design 621/1 'GAWRON' (see: Abandonment \& Reaction).

This Rules, published by PRS S.A. have not been formally put into service in the Polish Navy. They consist of ten parts and are directed to navie's, border guards, police and Polish and foreign shipowners, who want to classify their ships in PRS S.A. began issuing its Rules for the classification and construction of Naval Ships (NS) from Part I - Classification Regulations. The remaining parts of the Rules were

${ }^{14}$ Based on information prepared by J. Dilling from PRS S.A. 
successively developed and prepared for implementation ${ }^{15}$. The complete set of new Rules for the classification and construction of Naval Ships (NS) [4] (X parts, excluding special equipment) was entry into force on August 1, 2008 pursuant to Ordinance No. 16-P/08 of the PRS S.A. Management Board of June 24, 2008.

In preparation of the Rules by PRS S.A. participated the Polish Navy, Border Guard and Police. The standards, also military and civil and defence standards and procedures, both national and international, including NATO, EU and UN have been included in them. PRS S.A., according to the Act on the Polish Register of Shipping S.A., develops and implements ships classification and construction regulations, while Maritime Offices recognize all PRS S.A. documents as binding and in accordance with international law, allow to ships to move in Polish and foreign sea areas and ports. Issued by PRS S.A. maritime safety documents, including the technical security of the ship's structure, are accepted by all maritime administrations in the world.

\section{POLISH NAVY SHIPS UNDER THE SUPERVISION OF PRS S.A.}

In cooperation with the Polish Navy and 124th Regional Military Representative Office, PRS S.A. supervised the construction of a logistics support vessel type 130Z - ORP "Kontradmirał Xawery Czernicki". The result of this supervision was to give the ship a class certificate. Cooperation in supervision over the construction of the ship included issues related to strength analysis, verification of calculations, supervision of the hull, ship power plant, power and control systems, as well as issuing a compliance certificate - a certificate for the ship's air landing infrastructure.

PRS S.A. also supervised the construction of the prototype of the MCMV ORP 'Kormoran', supervised repair works of the hull of the frigate ORP 'Generał Kazimierz Pułaski' (fig. 3), certified the air landing infrastructure of both rocket frigates FFG-7 (Oliver Hazard Perry) and multitask logistical support ship ORP 'X. Czernicki' and supervises the ongoing construction: ORP 'Ślązak" (fig. 4), rescue ship and serial of mine-hunters and tugs. PRS S.A., as part of its activities, also performs expertises and prepares, depending on the needs, opinions for the division and organizational units of the Ministry of National Defence.

15 Part II — Hull, Part III — Hull Equipment, Part IV — Stability and Subdivision, Part V — Fire Protection, Part VI — Machinery Installations and Refrigerating Plants, Part VII — Machinery, Boilers and Pressure Vessels, Part VIII - Electrical Installations and Control Systems, Part IX Materials and Welding, Part X - Statutory Equipment.

2 (217) 2019 


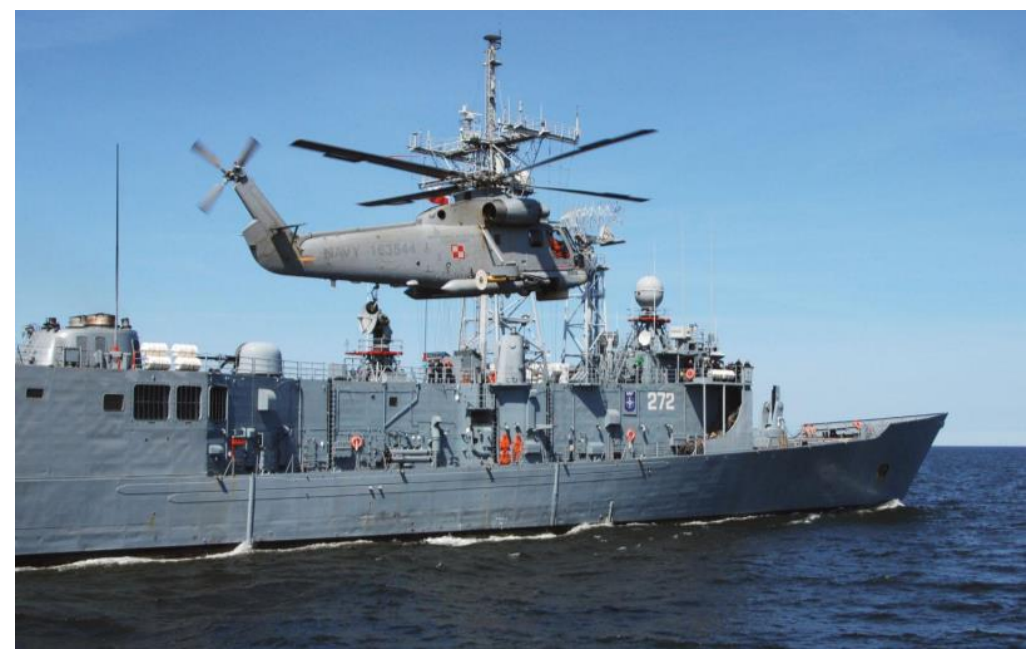

Fig. 3. ORP 'Generał Kazimierz Pułaski' [15]

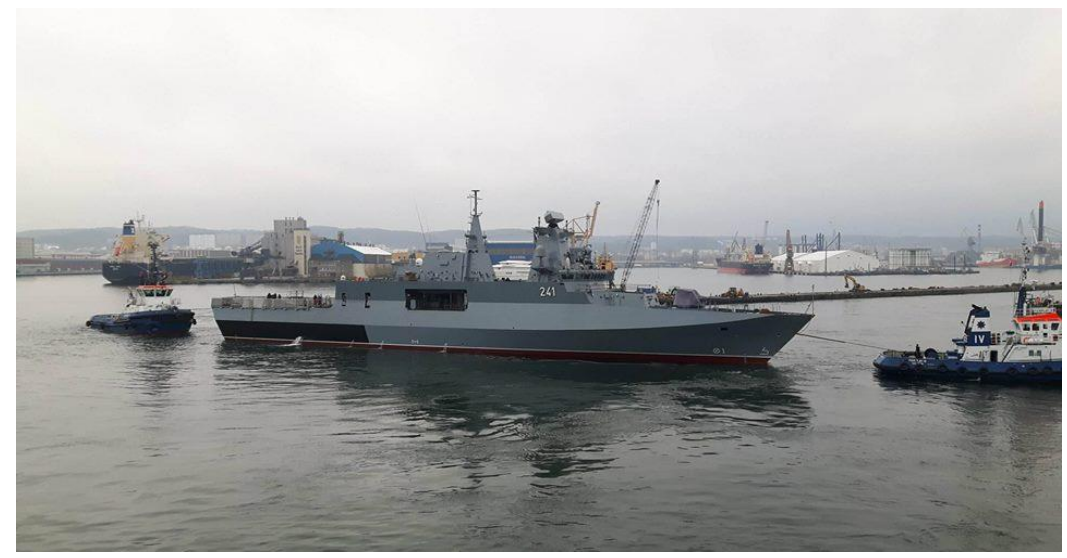

Fig. 4. 11 December 2017 ORP 'Ślązak' after leaving the dock of the Naval Shipyard S.A. in liquidation bankruptcy [13]

\section{PROPOSALS FOR ACTION}

The selected concepts and their definitions show that the ship is a military equipment. In terms of the scope of the regulations, shipbuilding regulations should be considered as a part of the military equipment acquisition system. The consequence of the above, in terms of the regulations for the design, construction, reception and utilization of ships, should be: 
- statutory legalization of the Minister of the National Defence ${ }^{16}$ for approval of regulations or guidelines for the design and construction of ships as generally applicable binding acts;

- preparation of own or recognition of PRS S.A. Rules and putting them into use by the Minister of National Defence as being in force in the Ministry of National Defence.

In terms of formal, there is the freedom of choice how to implemented in our formal and legal condition, this kind of legal act ${ }^{17}$. Depending on the formula adopted by the issuer of military equipment acquisition system, shipbuilding regulations may be issued as:

1. Annex to the current decision on the system of acquisition, utilization and withdrawing military equipment of the Polish Armed Forces [1].

Necessary action: requires amendment of Decision of the Minister of National Defence No. 141/MON regarding to the system of acquisition, utilizing and withdrawing military equipment of the Armed Forces of the Republic of Poland within the scope of its content and the introduction of a new annex (e.g. Rules for the principles of designing, construction, supervision and aacceptance of naval ships during the construction for the Polish Navy) and inclusion, in the content of the decision appeals to the introduced annex.

2. Separate legal act.

Neccessary action: requires the preparation and issuing of a separate decision of the Minister of National Defence, e.g. Rules for the principles of designing, construction, supervision and aacceptance of naval ships during the construction for the Polish Navy or the decisions on the recognition and introduction the regulations issued by the Polish Register of Shipping S.A. in the Ministry of National Defence. It will necessary to introduce, in the $\S 3$ of Decision of the Minister of National Defence No. 141/MON regarding to the system of acquisition, utilizing and withdrawing military equipment of the Armed Forces of the Republic of Poland, notation about not using the above decision in the field of construction of ships for the Polish Navy.

The door is open for decision makers but they always have different, more important tasks.

16 It requires changes to Act of December 14, 1995 on the Office of the Minister of National Defence and the Regulation of the Council of Ministers of July 9, 1996 on the detailed scope of action of the Minister of National Defence.

17 Decision of the Minister of National Defence - a legal norm that is not a source of universally binding law.

2 (217) 2019 


\section{CONCLUSIONS}

It is desirable to organize and preparate a holistic, coherent and rational approach to issues related to the life cycle of ships of the Polish Navy. The activities undertaken should focus on the legal and organizational aspects of the operation of shipbuilding, within the framework of the current military equipment acquisition system.

An integral part of this process should be, expected for many years, the introduction of the regulations for the designing, construction, supervision and acceptance of ships for the Polish Navy. The commencement of it depends on the possession, by the 'decision-making circles' of the State ${ }^{18}$ and of the Ministry of National Defence ${ }^{19}$, appropriate legal and normative-technical awareness.

It is also necessary for the Ministry of National Defence to begin a legislative initiative aimed to validating the Minister of National Defence to introduce, as applicable in the Ministry, the regulations for the design, construction, supervision and acceptance of ships. In addition, depending on the solution adopted (see: Proposals For Action), it may also be necessary to amend the Act on PRS S.A. in the scope of the possibility of preparation regulations also for the ships as military equipment.

Due to the issue by PRS SA, i.e. an independent and recognized international classification society, of its own naval ship classification and construction regulations ${ }^{20}$, it is reasonable for the Ministry of National Defence to take steps to put them into use in the Polish Navy, by way of e.g. ordinance of the Minister.

Prior to the introduction, these regulations should be verified and updated by the interested institutions and organizational units of the Ministry of National Defence, together with the preparation of the new missing part of the regulations regarding special equipment (armament, command and control systems, physical fields etc.).

18 Support for the activities of the Ministry of National Defence.

19 Legislative initiative.

20 The preparation by the Ministry of National Defence their own regulations seems to be irrational and long-lasting due to the lack of the institution responsible for the preparation and maintenance of the relevant regulations inside the Ministry, as well as the need for current access to standards of broadly understood technical safety of ships and shipping. 
Polish Navy shipbuilding regulations - example of neglect and lack of awareness...

\section{REFERENCES}

[1] Decyzja Ministra Obrony Narodowej nr 141/MON z dnia 5 lipca 2017 r. w sprawie systemu pozyskiwania, eksploatacji i wycofywania sprzętu wojskowego Sił Zbrojnych Rzeczypospolitej Polskiej, Dz.Urz. MON 2017, 149 [Decision of the Minister of National Defence No. 141/MON of 5 July 2017 regarding to the system of acquisition, utilizing and withdrawing military equipment of the Armed Forces of the Republic of Poland - available in Polish].

[2] Decyzja Ministra Obrony Narodowej $n r$ 72/MON z dnia 25 marca 2015 r. w sprawie pozyskiwania sprzętu wojskowego i usług dla Sił Zbrojnych Rzeczypospolitej Polskiej, Dz. U. 2013, poz. 78 z poźn. zm. [Decision of the Ministry of National Defence No. 72/MON of March 25, 2015 regarding to the acquisition of military equipment and services for the Armed Forces of the Republic of Poland — available in Polish].

[3] Instrukcja $w$ sprawie zasad projektowania, budowy i odbiorów jednostek pływających Marynarki Wojennej PRL, sygn. Mar. Woj. 943/85 [Instruction on the principles of designing, construction and commissioning of naval ships of the Polish People's Republic built in the Polish shipyards — available in Polish].

[4] Przepisy kwalifikacji i budowy okrętów wojennych (OW), PRS S.A., Gdynia 2008 [Rules for the classification and construction of Naval Ships (NS), issued by the Polish Register of Shipping S.A. - available in English], [online], https://www.prs.pl/przepisy-i-wydawnictwaprs/przepisy-klasyfikacyjne.html [access 02.04.2018].

[5] Rozporzq̨dzenie Rady Ministrów z dnia 9 lipca 1996 r. w sprawie szczegółowego zakresu działania Ministra Obrony Narodowej, Dz.U. 1996, 94, 426 z poźn. zm. [Ordinance of the Council of Ministers of July 9, 1996 on the detailed scope of action of the Minister of National Defence available in Polish].

[6] Ustawa z dnia 11 kwietnia 2001 r. o zmianie ustawy o Straży Granicznej oraz zmianie niektórych innych ustaw, Dz.U. 2001, 45, 498 [Act of April 11, 2001 amending the act on the Border Guard and amending some other acts - available in Polish].

[7] Ustawa z dnia 14 grudnia 1995 r. o urzędzie Ministra Obrony Narodowej, t.j. Dz.U. 2017, 2149 [Act of December 14, 1995 on the Office of the Minister of National Defence - available in Polish].

[8] Ustawa z dnia 18 sierpnia 2011 r. o bezpieczeństwie morskim, t.j. Dz.U. 2016, 281 [Act of August 18, 2011 on maritime safety - available in Polish].

[9] Ustawa z dnia 26 października 2000 r. o Polskim Rejestrze Statków, Dz.U. 2000, 103, 1098 z późn. zm. [Act of October 26, 2000 on the Polish Register of Shipping S.A. - available in Polish].

[10] Ustawa z dnia 9 listopada 2000 r. o bezpieczeństwie morskim, Dz.U. 2006, 99, 693 z późn. zm., [Act of November 9, 2000 on maritime safety — available in Polish].

[11] Zarzq̨dzenie nr 6 Ministra Spraw Wewnętrznych i Administracji z dnia 6 marca 2003 r. w sprawie uznania za obowiqzujące w stosunku do jednostek pływających Straży Granicznej przepisów technicznych z zakresu budowy $i$ wyposażenia statków wydanych przez polska instytucję klasyfikacyjna, Dz. Urz. MSWiA, Nr 3, poz. 8 [Ordinance No. 6 of the Minister of Internal Affairs and Administration of March 6, 2003 regarding the recognition of technical regulations in scope of the construction and equipment of ships issued by the Polish classification society - available in Polish]. 
[12] http://www.portalmorski.pl/stocznie-statki/37595-kormoran-odebrany-przez-marynarkewojenna-rp [access 01.04.2018].

[13] https://www.facebook.com/1442544729302079/photos/a.1997293240493889.107374184 $1.1442544729302079 / 1997293947160485 /$ type=3\&theater [access 01.04.2018].

[14] https://www.tvp.info/35289504/orp-kondor-opuszczenie-bandery?source=35289342 [access 01.04.2018].

[15] www.3fo.wp.mil.pl/pl/16.html [access 01.04.2018].

\section{PRZEPISY BUDOWY OKRETÓW MARYNARKI WOJENNEJ RP - PRZYKŁAD ZANIECHANIA \\ I BRAKUŚSIADOMOŚCI. SZKICPOLEMICZNY}

\section{STRESZCZENIE}

W artykule przedstawiono stan formalno-prawny w zakresie przepisów projektowania, budowy i wyposażania jednostek pływających MW RP. Obowiązujące w resorcie obrony narodowej przepisy nie są kompletne i w znacznym stopniu wpływają na ograniczone możliwości i efektywność prowadzenia budów nowych okrętów.

Artykuł prezentuje próbę usystematyzowania, pod względem pojęciowym, zagadnień dotyczących budowy nowych okrętów dla MW RP. Zasadniczą uwagę skupiono na zidentyfikowaniu występujących luk w przepisach, a także przedstawieniu propozycji ich wyeliminowania.

Słowa kluczowe:

budowa okrętów, przepisy, system pozyskiwania sprzętu wojskowego, towarzystwo klasyfikacyjne, logistyka marynarki wojennej.

Article history

Received: 08.05.2018

Reviewed: 28.03.2019

Revised: $\quad$ 08.04.2019

Accepted: 10.04.2019 